\title{
Rare but life-threatening complication of fecalith
}

\author{
Danny Mou, Rachel Atkinson, Monica Valero, Nelya Melnitchouk
}

Department of Surgery, Brigham and Women's Hospital, Boston, Massachusetts, USA

Correspondence to Dr Danny Mou, dmou2@partners.org

Accepted 16 June 2018

\section{DESCRIPTION}

A 78-year-old woman with history of Addison's disease, hypothyroidism, hypertension and recent hospital admission for asthma exacerbation requiring hospitalisation for steroid pulse presented to the emergency department with 1 day of significant epigastric and right lower quadrant pain. Her pain steadily worsened and was associated with nausea and clear emesis. She was on a steroid

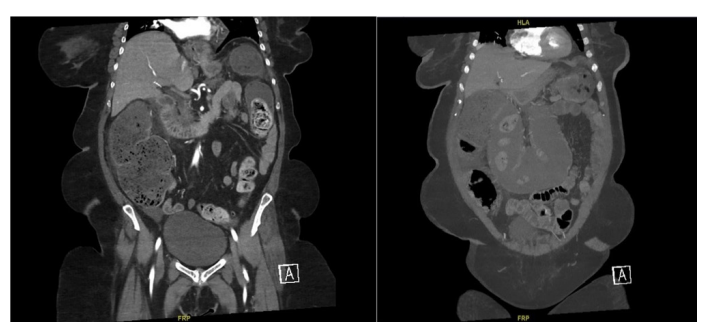

Figure 1 The left image displays a $4.1 \mathrm{~cm}$ obstructing fecalith in descending colon with clear transition point and significantly dilated caecum. There was no evidence of bowel wall thickening, fat stranding and perforation to suggest vascular compromise. Significantly dilated transverse colon seen in the right image.

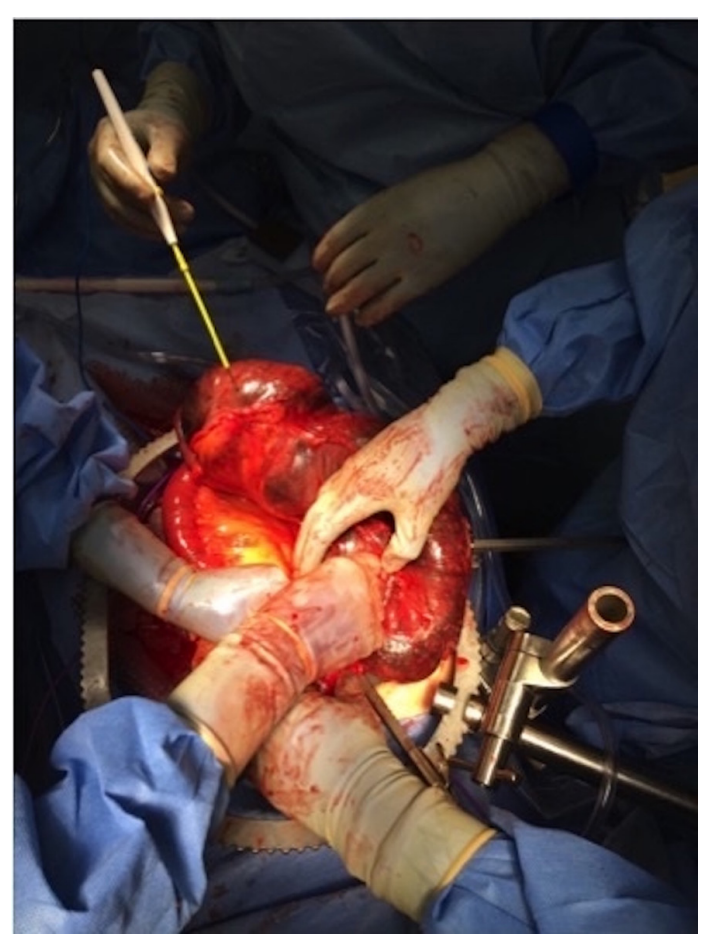

Figure 2 Intraoperatively, colon was frankly necrotic and foul smelling. There was murky fluid throughout abdomen, but no feculence or perforation was appreciated. A rock-hard fecalith was appreciated at the mid-descending colon and was mobile within the lumen. taper for her recent asthma exacerbation, and she is normally on baseline low-dose steroids for her Addison's disease.

On evaluation in the emergency department, the patient was noted to be tachycardic in the 100s but otherwise haemodynamically stable. Her abdomen was distended, and she endorsed moderate to severe tenderness over her right lower quadrant with guarding but no rebound. Her labs were notable for white cell count of $31.6 \times 10^{9} / \mathrm{L}$ and a lactate of $4.5 \mathrm{mmol} / \mathrm{L}$.

The patient was promptly fluid resuscitated, given intravenous antibiotics and analgesics. Given concern for bowel ischaemia, an abdominopelvic CT angiogram was obtained and revealed a $4.1 \mathrm{~cm}$ fecalith in the mid-descending colon causing significant dilation of transverse and ascending colon, with caecal dilation to $8.3 \mathrm{~cm}$ (figure 1). No pneumatosis, bowel wall thickening or inflammation was appreciated to suggest bowel ischaemia. Gastroenterology was asked to assess the patient for endoscopic fecalith removal, but the patient's blood pressures decreased to systolics of 90 s from 130 s with persistent tachycardia and worsening abdominal pain. Endoscopy was deferred and she was taken urgently to the operating room for exploratory laparotomy. On entry of her abdomen, it was apparent that her entire colon proximal to the fecalith was frankly necrotic (figure 2). There was no

\section{Learning points}

Fecaliths are generally considered a benign condition that can often be resolved with nonsurgical interventions, including mineral oil enemas, manual disimpaction and polyethylene glycol (either orally or through a nasogastric tube). If these interventions fail, endoscopic fragmentation of the fecalith may be necessary.

- Rarely, fecaliths can lead to more serious complications. Obstructive uropathy and stercoraceous ulcers are generally resolved with endoscopic removal of the obstructing fecalith. However, persistent intestinal obstruction leading to bowel wall compromise or perforation is a surgical emergency.

- This case illustrates a rare but life-threatening complication of fecalith. The patient developed a necrotic colon and was symptomatic over just a 24-hour period. Moreover, fecalith complications are usually present in patients who are institutionalised or have neurologic disorders (eg, paraplegics). Our patient was an overall healthy woman who was living independently, suggesting that complications are not restricted to specific patient populations. 
overt perforation, but there was murky fluid appreciated throughout abdomen. A subtotal colectomy with end ileostomy was performed. Her abdomen was copiously irrigated and her incisions were closed primarily.

She was admitted to the intensive care unit postoperatively and recovered well. She was extubated and weaned off all vasopressors on postoperative day 1 and her ileostomy was functioning by postoperative day 5 . She was discharged to a rehabilitation facility 2 weeks after her surgery.
Contributors Conception or design of the work: DM, MV, NM. Data collection: DM, MV, NM. Data analysis and interpretation: DM, RA, MV, NM. Drafting the article: DM, RA. Critical revision of the article: DM, RA, MV, NM. Final approval of the version to be published: DM, RA, MV, NM.

Funding The authors have not declared a specific grant for this research from any funding agency in the public, commercial or not-for-profit sectors.

Competing interests None declared.

Patient consent Obtained.

Provenance and peer review Not commissioned; externally peer reviewed.

Copyright 2018 BMJ Publishing Group. All rights reserved. For permission to reuse any of this content visit http://group.bmj.com/group/rights-licensing/permissions.

BMJ Case Report Fellows may re-use this article for personal use and teaching without any further permission.

Become a Fellow of BMJ Case Reports today and you can:

- Submit as many cases as you like

- Enjoy fast sympathetic peer review and rapid publication of accepted articles

- Access all the published articles

Re-use any of the published material for personal use and teaching without further permission

For information on Institutional Fellowships contact consortiasales@bmjgroup.com

Visit casereports.bmj.com for more articles like this and to become a Fellow 